\title{
A VÍZHÁZTARTÁS VIZSGÁLATA NÉHÁNY KISKUNSÁGI FAÁLLOMÁNYBAN
}

\author{
Bolla Bence ${ }^{1}$, Németh Tamás Márton ${ }^{1}$ és Gácsi Zsolt ${ }^{2}$ \\ ${ }^{1}$ NAIK Erdészeti Tudományos Intézet, Ökológiai és Erdőmüvelési Osztály \\ ${ }^{2}$ Kiskunsági Erdő-Gazda Kft.
}

\begin{abstract}
Kivonat
Vizsgálatainkat a Duna-Tisza közi homokhát területén elhelyezkedő három erdörészletben, és a közvetlen közelükben lévő gyepterületeken folytattuk 2012-2015 között. Munkánk során különbözö módszereket alkalmaztunk a kísérleti területek vízháztartásának vizsgálatához. Bizonyítottuk, hogy a vizsgált gyepterületek vízforgalma jelentősen különbözik a közvetlen környezetükben elhelyezkedő erdőállományokétól. A különböző alföldi erdőallományokban és a szomszédos fátlan területeken végzett hidrológiai mérések hozzájárulhatnak ahhoz, hogy a gyakran szélsőséges vízháztartási viszonyok között folytatott alföldi erdőgazdálkodás minél inkább alkalmazkodni tudjon a klímaváltozás okozta kihivásokhoz.
\end{abstract}

Kulcsszavak: Kiskunság, erdőállomány, csapadék, talajnedvesség, intercepció, vízháztartás

\section{MONITORING OF THE HYDROLOGICAL BALANCE IN FOREST STANDS OF KISKUNSÁG}

\begin{abstract}
The aim of this paper to show how hydrological measurements in forests and grasslands can contribute to the treatment of different areas. The study was carried out in three different forest stands and their surrounding grasslands of the area of the Kiskunság Sandridge, between 2012 and 2015. Different methods were applied during the study of the water balance. The water balance shows that the values of the water uptake of the grasslands are lower than that of the surrounding foreststands. The hydrological measurements and results can be useful for the sylviculture in different sand forest types under the changing climate conditions.
\end{abstract}

Keywords: Kiskunság, forests, precipitation, soil moisture, interception, water balance 


\section{BEVEZETÉS}

Az Alföldfásitási Program eredményeként Alföldünk erdősültsége a II. világháború előtti 4,5\%-ról napjainkra megháromszorozódott (Országos Erdoállomány Adattár adatai alapján). E nagyszabású erdősitési munka megkívánta, hogy sokszor a negatív vízmérlegü - párologtató típusú - talajokon is erdőállományokat hozzanak létre.

A Duna-Tisza közén az 1970-es évektöl jelentős talajvízszint-süllyedés következett be, melynek méretei az 1990-es évek közepére tovább romlott. Az okok kutatásával - a téma fontosságának megfelelően - számos szakember foglalkozott (Major 1974, 1994, 2002, Major \& Neppel 1988, Szodfridt 1974, 1990, 1993, Pálfai 1995, 2010). A probléma rendkívüli összetettsége miatt a különböző szakterületek müvelői csak részterületekröl nyilatkozhatnak felelösséggel. A jelenség ráirányította a figyelmet az alföldi erdeink vízháztartási kérdéseire is.

Az erdő-víz kapcsolatot elemző kutatások természetesen nem merülhetnek ki az erdők talajvízszintre gyakorolt hatásának tanulmányozásában. A természetvédelem, a vízügy, a mezőgazdaság és nem utolsó sorban a táji erdőgazdálkodás szemszögéböl nézve is egyre fontosabb annak megismerése, hogy milyen szerepet töltenek be az alföldi erdők a térség vízháztartásában. Jelen munkánkkal e problémakör vizsgálatához szeretnénk hozzájárulni.

\section{ANYAG ÉS MÓDSZER}

\section{Vizsgálati terület}

A kiskunsági homokháton összesen 5 mintaterületet jelöltünk ki. Bócsán egy-egy, azonos korú (41 év) és azonos technológiával létesített erdeifenyvest és hazai nyárast vizsgáltunk; kontrollként a mellettük lévő tisztás szolgált. Pusztaszeren egy sarj eredetű, idős (44 éves), elegyetlen akácost és a mellette lévő gyepterületet választottuk (1. ábra). A vizsgált faállományok képe erősen heterogén, jellemző a pusztuló állományfoltok és a gyenge fejlődés (erdeifenyves 5., a szürke nyáras 6 . és az akácos 6 . fatermési osztályú). Az állományok alacsony élő fakészlettel rendelkeznek (erdeifenyves 170 , szürke nyáras 190, akácos $100 \mathrm{~m}^{3} / \mathrm{ha}$ ) és rossz az egészégi állapotuk is (az Országos Erdőállomány Adattár adatai alapján).

\section{Alkalmazott módszerek}

A szabadterületi csapadék meghatározásához Hellmann-rendszerü csapadékmérőket használtunk. Az áthulló csapadékot és a törzsi lefolyást az erdeifenyvesben (Bócsa 51/D) és a szürke nyárasban (Bócsa 51/E) mértük. A lombkoronán áthulló csapadék mennyiségét mintaterületenként, három darab Hellmannrendszerü csapadékmérő (egy a sorközben, egy sorban és egy záródáshiányos foltban kihelyezve), húsz darab $280 \mathrm{~cm}^{2}$ felületü tölcsér (1×1 m-es kötésben kialakitva) és tíz darab $100 \mathrm{~cm}^{2}$ felületü mérőedény (véletlenszerüen elhelyezve) segítségével mértük. A törzsön lefolyó csapadékvíz mennyiségét az átmérőeloszlás figyelembevételével, törzsgallérokkal határoztuk meg.

A meteorológiai adatokat (hőmérséklet, relatív páratartalom, szabadterületi csapadék, globálsugárzás) a bócsai kontrollterületen (Bócsa 51/TI1) létesített BOREAS Meteo Global HI meteorológiai méróállomás segítségével, óránkénti felbontásban észleltük (2. ábra).

A három év alatt gyüjtött hőmérséklet- és csapadékadatok összevetését legcélszerübb a Walter-Lieth-féle klímadiagram összefüggéseinek segítségével elvégezni, mivel ez a módszer szemlélteti az egyes időszakok 
(pl.:humid, aszályos) alakulását. A diagramot három év jellemzésére készítettük el, így az nem tekinthető klaszszikus Walter-Lieth-féle klímadiagramnak. Az egyes éveket az az erdészeti szárazsági index (Führer 2010) alapján is jellemezztük.

A talajvízszint adatait a bócsai és a pusztaszeri mintaterületeken kialakított monitoring kutakban Dataqua, DA-LUB 222 nyomásszondák és HYGR adatgyüjtők, valamint Dataqua, DA-OP LED diódás, kézi vízszintmérő segítségével gyüjtöttük (óránkénti, illetve az adatgyüjtő meghibásodása esetén heti rendszerességgel).

A talajnedvesség adatait kézi mérőműszer és automata mérőállomás segítségével gyüjtöttük Bócsán három helyszínen. A talaj felső $80 \mathrm{~cm}$-es nedvességtartalmát TDR-rendszerű PT-1 digitális talajnedvességmérő egységgel mértük heti gyakorisággal. Az automatizált talajnedvesség méréseket az Onsetcomp által gyártott HOBO MicroStation adatgyüjtővel és Decagon10 HS talajnedvesség szenzorok (12 db) alkalmazásával végeztük óránként, mintaterületeként négy talajrétegben $(0-25 \mathrm{~cm}, 25-50 \mathrm{~cm}, 50-75 \mathrm{~cm}, 75-100$ $\mathrm{cm})$. Két alkalommal a begyüjtött talajminták nedvességtartalmát szárítószekrény segítségével határoztuk meg.
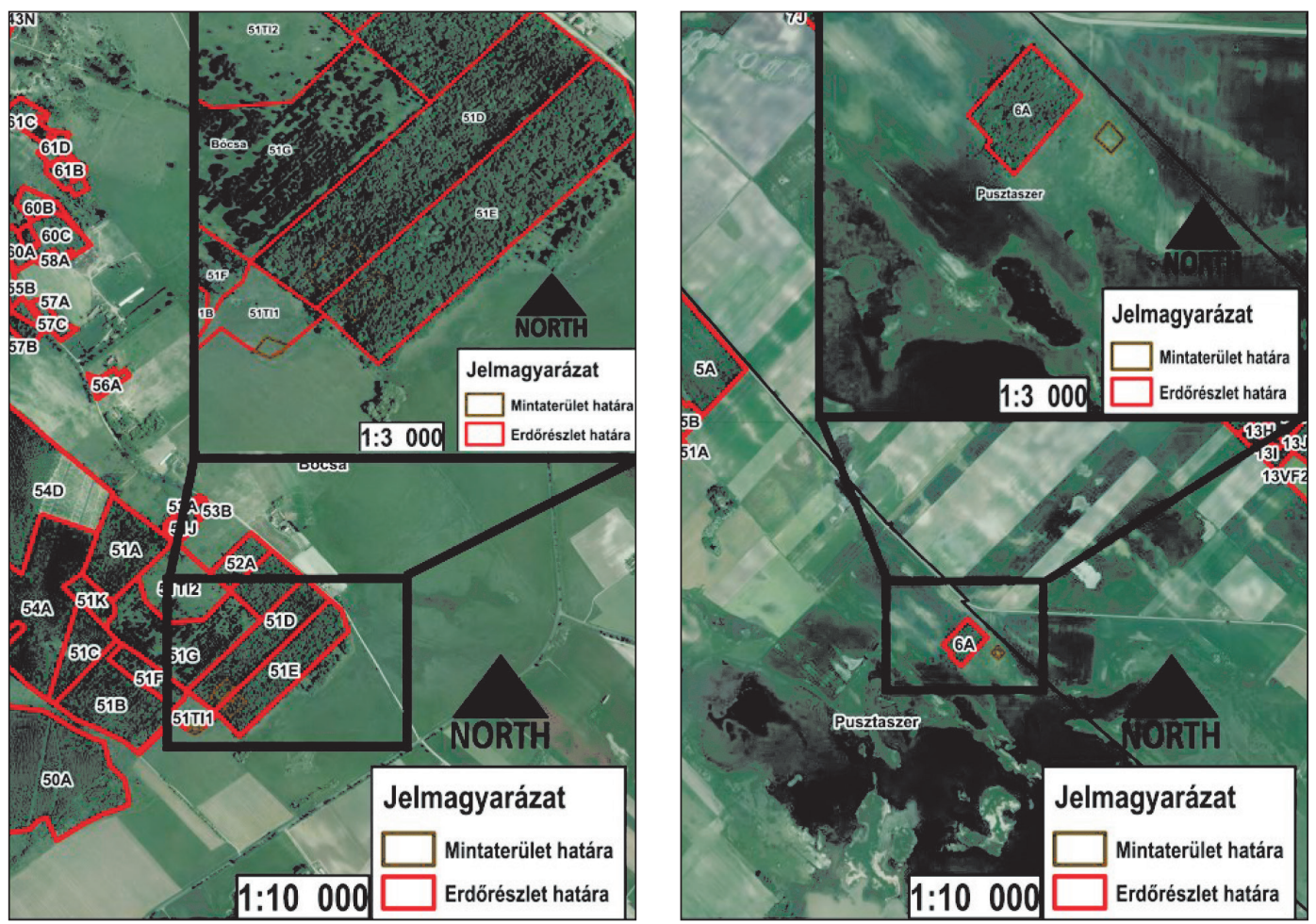

1. ábra: A mintaterületek elhelyezkedése (Bócsa és Pusztaszer)

Figure 1: Study sites (Bócsa and Pusztaszer) 

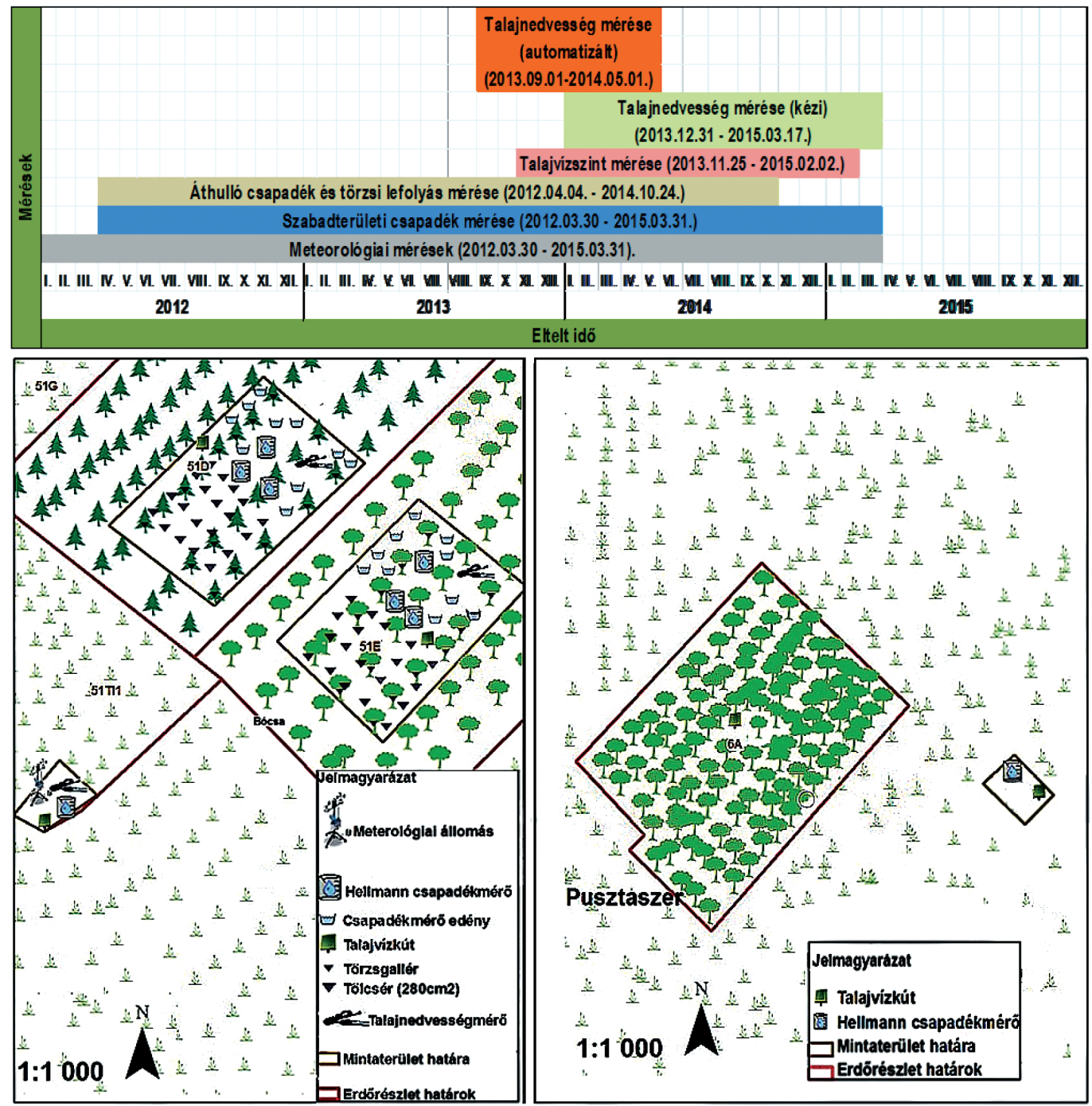

2. ábra: A mérési intervallumok és a mérőeszközök elhelyezkedése

Figure 2: Measuring periods and locations of the sensors

\section{Adatok feldolgozása}

A kiértékelés módszertanát nagyban meghatározta, hogy az adott évben milyen méréseket tudtunk elvégezni.

A rendkívül eltérő csapadékviszonyokkal jellemezhető évek miatt az intercepciót minden vizsgált év vegetációs időszakára (április és szeptember közötti időszak) meghatároztuk. A nyugalmi időszak intercepcióját nem vizsgáltuk. Az eltérések okainak magyarázatához az egyes évek csapadékadatait részletesen bemutatjuk.

A legteljesebb körü adatokkal a 2014-es évre rendelkezünk, a talajnedvesség adatok lehetőséget adtak a vízháztartási egyenlet felállitására is. 
Egy adott erdőterület vízháztartása a következő egyenlettel írható fel (Szász \& Tőkei 1997):

$$
\Delta S=\left(\mathrm{Cs}_{\mathrm{M}}+\mathrm{Cs}_{\mathrm{m}}+\mathrm{H}_{\mathrm{f}}+\mathrm{H}_{\mathrm{fa}}+\mathrm{K}\right)-\left(\mathrm{P}+\mathrm{E}_{\mathrm{f}}+\mathrm{E}_{\mathrm{fa}}+\mathrm{Sz}+\mathrm{I}\right)
$$

(maradéktag) (bevételi tagok) (veszetségi tagok)

ahol az egyenlet változói: $\quad \Delta \mathrm{S}$ : A vizsgálta talajréteg vízkészlet-változása [mm]

$\mathrm{Cs}_{\mathrm{M}}$ : A hulló csapadék [mm]

$C s_{\mathrm{m}}$ : A mikrocsapadék [mm]

$\mathrm{H}_{\mathrm{f}}$ : A felszíni hozzáfolyás [mm]

$\mathrm{H}_{\mathrm{fa}}$ : A felszín alatti hozzáfolyás [mm]

K: Kapilláris úton felemelt vízmennyiség [mm]

P: Párolgás, amely a növényi transzspiráció és a talajfelszín evaporációja [mm]

Ef: Felszíni elfolyás [mm]

$\mathrm{E}_{\mathrm{fa}}$ : Felszín alatti elfolyás [mm]

Sz: Mélybeszivárgás [mm]

I: Intercepció [mm]

E vízháztartási egyenletet a talajnedvesség-szondák által átfogott talajrétegre, azaz $80 \mathrm{~cm}$-es vastagságra írtuk fel. A mélyen húzódó talajvíz ( $3 \mathrm{~m}$ ) és a sík terep miatt egyenletünk jelentősen egyszerüsíthető; kiesik a kapilláris úton felemelt víz $(K)$ és a felszíni és felszín alatti hozzá-, ill. elfolyás $\left(H_{f}, H_{f a}, E_{f}, E_{f a}\right)$. A módszer pontossága megengedi a mikrocsapadék $\left(\mathrm{CS}_{\mathrm{m}}\right)$ mennyiségének elhanyagolását is. A mélybeszivárgás maradéktagként adódik, így jelen esetben a $80 \mathrm{~cm}$ alá beszivárgó csapadékvíz mennyiségét jelenti.

A fentiek alapján a felső $80 \mathrm{~cm}$-re felírható a síkvidéki, mély talajvizủ erdők egyszerüsített vízháztartási egyenlete (amelyet Gácsi 2000 és Móricz 2011 is alkalmazott):

$$
\Delta \mathrm{S}=\left(\mathrm{Cs}_{\mathrm{M}}\right)-(\mathrm{P}+\mathrm{Sz}+\mathrm{l})
$$

A talaj nedvességkészletének változását $(\Delta S)$, a hulló csapadékot $\left(\mathrm{Cs}_{\mathrm{M}}\right)$, és az intercepciót (I) mértük. Az evapotranszspirációt a vízháztartási egyenlet csapadékmentes időszakokra történő felírásával számítottuk (az intercepció és a mélybeszivárgás értéke kiesik, így a talaj nedvességkészletének változása az evapotranszspiráció értékével egyenlő (Moltschanow 1957).

Habár az előző számolás során a kapilláris vízemeléssel, mint bevételi taggal nem kell számolnunk, elöfordulhat, hogy a $3 \mathrm{~m}$ alatt húzódó talajvízből is van növényi vízfelvétel. Ekkor az egyszerüsített vízháztartási egyenletből számolt evapotranszspirációs érték a tényleges értéket alulbecsli, hiszen a módszer nem számol a talajvízböl való növényi vízfelvétellel.

A fenti probléma miatt meg kell vizsgálnunk, hogy a növényzet jut-e többletvízhez a mélyen húzódó talajvízből. A kapilláris zónából történő vizfelvételt a White-féle módszer alapján határoztuk meg (White 1932, Loheide et al 2005):

$$
\mathrm{ET}=\mathrm{S}_{\mathrm{y}}(24 \mathrm{r} \pm \mathrm{s})
$$

ahol az egyenlet változói: $\quad$ ET: A kapilláris zónából történő vízfelvétel [mm/nap]

$\mathrm{S}_{\mathrm{y}}$ : A talajra jellemzö fajlagos hozam (amelyet Loheide grafikonja alapján becsültünk) [mértékegység nélkül]

r: A talajvízgörbéhez húzott egyenes iránytangense a vizsgált időszakban [mm/óra]

s: egy nap alatt még egy (s) értékkel jellemezhető csökkenés is beáll a talajvízszintben [mm/nap] 
A White-módszer a kapilláris zónából történő növényi vízfelvételt a talajvíz napi periódusú ingadozása alapján becsli. Amennyiben a késő éjjeli, kora hajnali időszakban (0.00-4.00 óra között) az evapotranszspirációt elhanyagolhatónak tételezzük fel, akkor ebben az időszakban a talajvizállás növekedési rátáját egyenlönek vehetjük a terület talajvíz utánpótlódásával. A görbéhez ebben az időszakban húzott egyenes iránytangense (r), tehát az egységnyi idő (pl.: 1 óra) alatti talajviz-utánpótlódás. Ha ezt az utánpótlódási rátát, evapotranszspiráció jelenléte nélkül meghosszabbítanánk 24 órán keresztül, akkor a talajvízszint 24r magasságra emelkedne. Mivel azonban az evapotranszspiráció jelen van, általában a növekedés helyett egy nap alatt még egy (s) értékkel jellemezhető csökkenés is beáll a talajvízszintben (Gribovszki et al 2009).

A talajvízgörbe négy szakaszát vizsgáltuk, ahol növényi vízfelvételt feltételeztünk a talajvízszint változása alapján (2014. 05. 04. - 2014. 05. 08., 2014. 06. 02. - 2014. 06. 16., 2014. 07. 13. - 2014. 07. 18., 2014. 08. 11. - 2014. 08. 23.). A talajvízszondák cm-es felbontásban észlelték a talajvízszint változását így kézi leolvasást alkalmazva választottuk ki a vizsgálandó szakaszokat és ezekre alkalmaztuk a White-féle módszert.

\section{EREDMÉNYEK ÉS MEGVITATÁSUK}

\section{Csapadékadatok értékelése}

A lehullott csapadék mennyisége a vizsgálat 3 évében rendkivül változatos képet mutatott. A 2012-es év rendkívül aszályos, a 2014-es átlagon felül csapadékos volt.

A Bócsán, ill. Pusztaszeren mért csapadékadatok kumulált görbéi hasonló lefutást mutatnak. Az összegző görbék elnyúlása jól mutatja a csapadékmentes időszakokat (3. ábra).

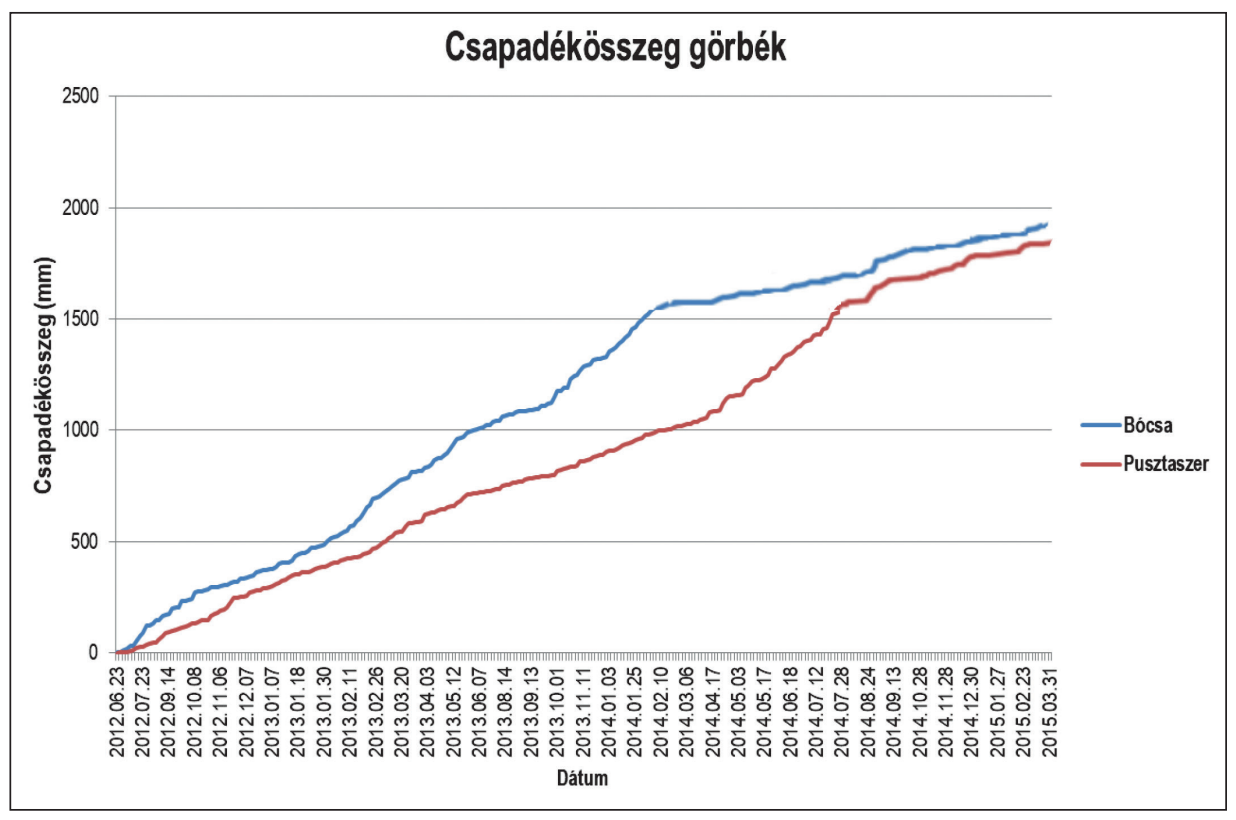

3. ábra: A csapadék összeggörbe változása mintaterületenként (2012. április és 2015. március között)

Figure 3: The change in precipitation amount curve of the study sites (April 2012-March 2015) 

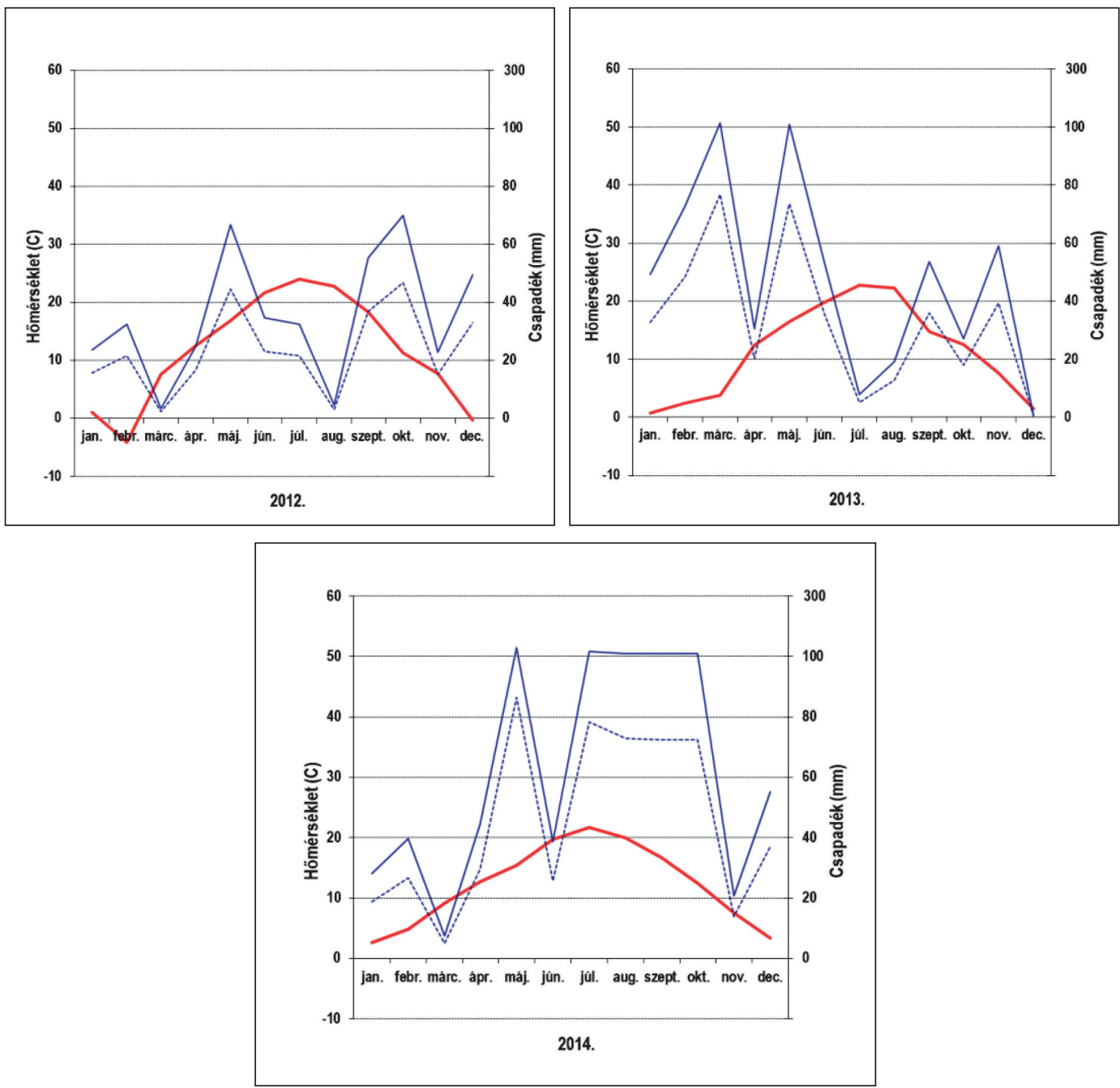

4. ábra: A Bócsa 51 TI1 meteorológiai adatainak ábrázolása 2012-2014 között (a Walter-Lieth-féle klímadiagram összefüggései alapján) Figure 4: Meteorological data between 2012-2014 in Walter-Lieth's diagram context (Bócsa 51 TI1)

A klímadiagram alapján aszályos időszakkal 2012-ben március, július és augusztus, 2013-ban augusztus és 2014-ben március hónapokban találkoztunk. Ezen túl több aszályveszélyes időszak is tapasztalható volt, jellemzően a tavaszi és nyári hónapokban. A humid időszakok elrendeződése 2012 és 2014 között igen heterogénnek mondható, ami a csapadékesemények változatos területi és időbeli eloszlásával magyarázható. Szuperhumid időszak mindössze háromszor (2013 februárjában, 2014 májusában és júliusában) jellemezte a bócsai mintaterület időjárását. A vizsgálati időszak alatt fagyos hónap csak 2012-es év január, február és december havában volt. Fagyveszélyes hónapokkal viszont annál többel találkozhatunk jellemzően januárban, februárban, márciusban, novemberben és decemberben (4. ábra).

Mivel a klímadiagram a havi értékek figyelembevételével készült, így nem mutatja igazán jól a szélsőségek hatását, illetve bizonyos mértékben elfedi azokat. Tehát nem csak a havi, hanem a napi értékek is meghatározó szereppel bírnak az adott faállomány további fejlődését tekintve. 
Ha az erdészeti szárazsági index (Führer 2010) alapján jellemezzük az elmúlt éveket akkor a 2012-es és 2013-as évek erősen az erdőssztyep klímába (FAl értékek: 13,69, 11,33), viszont 2014 - jelentős/extrém mennyiségű csapadék hatására - a bükkös klímába sorolható (FAl érték: 4,07).

Az intercepciós vizsgáltok értelmezéséhez közreadjuk a meteorológiai állomás és a kézi csapadékmérések vegetációs időszakra vonatkozó adatait (1. táblázat).

1. táblázat: Az egyes vegetációs időszakok meteorológiai jellemzői

Table 1: The meteorological elements of each vegetation period

\begin{tabular}{|l|c|c|c|}
\hline \multirow{2}{*}{ Meteorológiai adatok } & 2012 & 2013 & 2014 \\
\cline { 2 - 4 } & \multicolumn{3}{|c|}{ Vegetációs időszak (03. 31. - 09. 01.) } \\
\hline Csapadék & $164 \mathrm{~mm}$ & $224 \mathrm{~mm}$ & $428 \mathrm{~mm}$ \\
\hline Csapadékos nap & $49 \mathrm{nap}$ & $51 \mathrm{nap}$ & $70 \mathrm{nap}$ \\
\hline $5 \mathrm{~mm}$ alatti csapadék & $40 \mathrm{nap}$ & $37 \mathrm{nap}$ & $45 \mathrm{nap}$ \\
\hline Relatív páratartalom & $62,3 \%$ & $66,8 \%$ & $70,9 \%$ \\
\hline Átlaghömérséklet & $19,6{ }^{\circ} \mathrm{C}$ & $18,7^{\circ} \mathrm{C}$ & $18,00^{\circ} \mathrm{C}$ \\
\hline Globálsugárzás (átlag) & $2099 \mathrm{~J} / \mathrm{cm}^{2}$ & $2110 \mathrm{~J} / \mathrm{cm}^{2}$ & $1983 \mathrm{~J} / \mathrm{cm}^{2}$ \\
\hline
\end{tabular}

\section{Intercepció és törzsi lefolyás}

Az intercepciós adatokat két szemszögből értékeltük. Egyrészt a 2014-re számolt vízmérleghez megadtuk az intercepció értékét (2. és 3. táblázat), másrészt azt vizsgáltuk, hogy az igen eltérő meteorológiai jellemzőkkel leírható 2012, ill. 2014. évek intercepciójában megfigyelhető-e jelentős különbség.

2. táblázat: Intercepció és törzsi lefolyás az erdeifenyves állományban (Bócsa 51/D)

Table 2: Interception and stem-flow in the Scots pine stand (Bócsa 51/D)

\begin{tabular}{|c|c|c|c|}
\hline \multirow{2}{*}{ Jellemzők } & 2012 & 2013 & 2014 \\
\hline & \multicolumn{3}{|c|}{ Vegetációs időszak (03. 31. - 09. 01.) } \\
\hline Csapadék & $164 \mathrm{~mm}$ & $224 \mathrm{~mm}$ & $428 \mathrm{~mm}$ \\
\hline Koronán áthulló csapadék & $115 \mathrm{~mm}(70 \%)$ & $156 \mathrm{~mm}(70 \%)$ & $319 \mathrm{~mm}(74,5 \%)$ \\
\hline Törzsi lefolyás & $3 \mathrm{~mm}(2 \%)$ & $9 \mathrm{~mm}(4 \%)$ & $11 \mathrm{~mm}(2,5 \%)$ \\
\hline Állományi csapadék összeg & $118 \mathrm{~mm}(72 \%)$ & $165 \mathrm{~mm}(74 \%)$ & $330 \mathrm{~mm}(77 \%)$ \\
\hline Intercepció & $46 \mathrm{~mm}(28 \%)$ & $59 \mathrm{~mm}(26 \%)$ & $98 \mathrm{~mm}(23 \%)$ \\
\hline
\end{tabular}

Az erdeifenyvesben a különböző évek vegetációs időszakainak intercepciója között jelentős eltéréseket találtunk. Legmagasabb a 2012-es vegetációs időszak intercepciója volt (28\%), míg 2014-ben ennek csak 82\%-át tapasztaltuk (23\%). A \%-ban kifejezett intercepciót növeli a kis csapadékú csapadékesemények magas aránya és a nagyobb páraéhség (kisebb relatív páratartalom, magasabb átlaghőmérséklet). Az 1. táblázatban közölt meteorológiai adatok a fent leírtakat egyértelmüen alátámasztják a gyakorlatban is.

Különösen fel szeretnénk hívni a figyelmet a kis csapadékok (legfeljebb $2 \mathrm{~mm}$ ) jelentőségére. Abban az esetben, ha a $2 \mathrm{~mm}$ alatti csapadékú napokat az intercepció számításánál figyelmen kívül hagynánk a fent jellemzett és magyarázott intercepciós különbségek eltűntek volna (2012: 22\%, 2013: 24\%, 2014: 23\%). Ennek egyértelmű oka, hogy 2 mm alatti csapadéknál az átlagos intercepció 99\% is lehet (Sitkey 1999). 
3. táblázat: Intercepció és törzsi lefolyás a szürke nyáras állományban (Bócsa 51/E)

Table 3: Interception and stem-flow in the grey poplar stand (Bócsa 51/E)

\begin{tabular}{|c|c|c|c|}
\hline \multirow{2}{*}{ Jellemzők } & 2012 & 2013 & 2014 \\
\hline & \multicolumn{3}{|c|}{ Vegetációs időszak (03. 31. - 09. 01.) } \\
\hline Csapadék & $164 \mathrm{~mm}$ & $224 \mathrm{~mm}$ & $428 \mathrm{~mm}$ \\
\hline Koronán áthulló csapadék & $117 \mathrm{~mm}(71 \%)$ & 152 mm (68\%) & $304 \mathrm{~mm}(71 \%)$ \\
\hline Törzsi lefolyás & 13 mm (8\%) & $27 \mathrm{~mm}(12 \%)$ & $43 \mathrm{~mm}(10 \%)$ \\
\hline Állományi csapadék összeg & $130 \mathrm{~mm}(79 \%)$ & 179 mm (80\%) & $347 \mathrm{~mm}(81 \%)$ \\
\hline Intercepció & $34 \mathrm{~mm}(21 \%)$ & $45 \mathrm{~mm}(20 \%)$ & $81 \mathrm{~mm}(19 \%)$ \\
\hline
\end{tabular}

A szürke nyárasban mért adatok kiértékelésénél szembetűnik, hogy a koronán áthulló csapadék menynyisége az egyes években csaknem megegyezik a szomszédos fenyvesben mért értékekkel. A különbséget a nyárasban mért nagyobb törzsi lefolyás adja. A jelenség mindkét faállomány alacsony záródásával és (a gyenge termőhely miatt kialakult) rossz egészségi állapotával magyarázható.

Az intercepciós értékek meteorológiai jellemzőktől való függése a szürke nyárasban is kifejezésre jut, de sokkal kevésbé, mint azt az erdeifenyves esetében láttuk.

A gyepterületek intercepcióját Hagyó et al (2006) bugaci méréseit felhasználva adtuk meg. Az akácos faállomány intercepcióját Járó (1980) eredményei alapján határoztuk meg.

\section{Talajvízszint alakulása}

A bócsai kísérleti területek alatt mért talajvízszinteket mutatja be az 5. ábra.

A kontroll kútban a talajvízszint átlagosan 3,06 m-es mélységben volt. Gácsi 2000-ben közreadott Bugacon mért adataival és az Alsó-Duna-Völgyi Vízügyi Igazgatóság észleléseivel (Orgovány, 2014: 3,5 m, Bócsa, 2014: 3,3 m) összevetve ez az érték a helyi átlagnak megfelelő. A megfigyelés teljes időtartama alatt e kútban mért talajvízszint volt a legmagasabb. A mérési időszakban a talajvízszint növekedése volt megfigyelhető a 2014 nyarán és őszén hullott csapadékoknak köszönhetően.

A fenyvesben $10 \mathrm{~cm}$-rel volt mélyebben a talajvíz szintje, mint a kontrollterületen. Ez az érték a vegetációs időszak során sem növekedett jelentősen, a talajvíz ingása a teljes vizsgált időszakban sem haladta meg a $25 \mathrm{~cm}$-t. A csapadékeseményekre a parlagterület alatti vízszint gyorsan, viszonylag erősen reagált, de a különbségek rendre kiegyenlítődtek. A legnagyobb vízszintkülönbség $(50 \mathrm{~cm})$ a következő nyugalmi időszak során alakult ki. Az erdőállomány alatti vegetációs időszaki depresszió nem volt kimérhető. Ez alapján feltételezhető, hogy az állomány közvetlenül a talajvízből nem fogyaszt - talajvízszintre gyakorolt hatása inkább az intercepción keresztül érvényesül. Talajvízből való közvetlen vízfogyasztást a White-módszerrel sem tudtunk kimutatni (0 mm/nap).

A Bócsa 51 E szürke nyáras alatt a nyugalmi időszakban $50 \mathrm{~cm}$-rel mélyebben állt a talajvíz, mint a parlagterület alatt. Ez a különbség a vegetációs időszak során elérte az $1 \mathrm{~m}$-t, majd a következő nyugalmi időszakra visszaállt a korábban mért $50 \mathrm{~cm}$ körüli különbség. Az 5. ábrán látható depresszióból arra következtethetünk, hogy az állomány közvetlenül is fogyaszt a talajvízből. Ennek értékét a 2014-es vegetációs időszakban a White-módszerrel $1,5 \mathrm{~mm} /$ napra (230 mm/veg. idősz.) becsültük. 


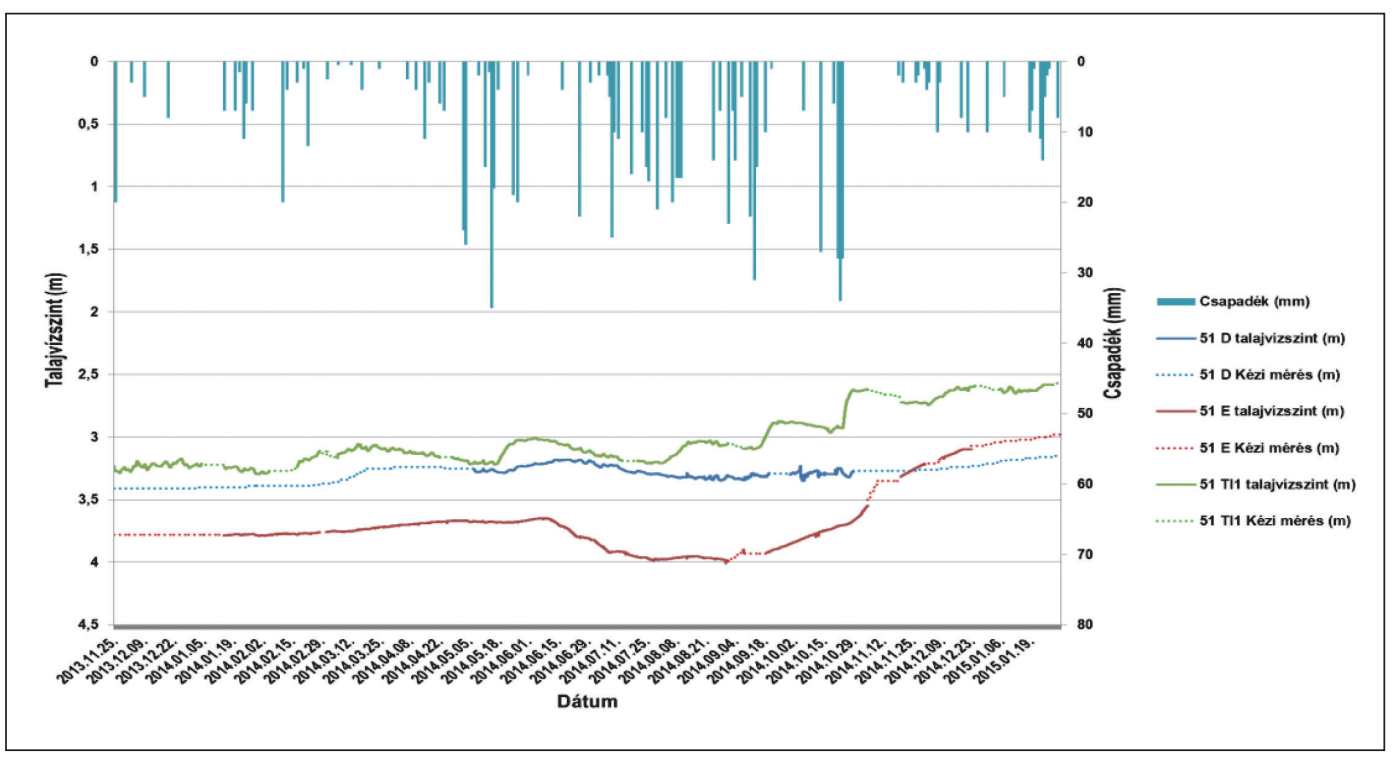

5. ábra: A talajvízszint alakulása Bócsán a napi csapadékok függvényében

Figure 5: Changes in the groundwater level in Bócsa depending on the precipitation

A pusztaszeri parlagkútban a talajvízszint átlagos mélysége 1,2 m volt. Ez az érték a Homokhátságon átlag feletti az Alsó-Tisza-vidéki Vízügyi Igazgatóság 2014-es ópusztaszeri (2,8 m) és balástyai (2,9 m) méréseihez képest. A kontrollterületként kijelölt gyepterület talajvízszintje a szabad területi csapadék ciklikusságához, illetve a közeli Büdös-szék vízállásához igazodik. A vegetációs időszakban a talajvízszint periodikus csökkenése volt megfigyelhetö, majd a nyugalmi időszakban annak folyamatos emelkedése volt tapasztalható (6. ábra). A talajvízszint ingadozásának maximum értéke 1,1 m, ami a közeli Büdös-szék vízállásának fokozatos növekedésével (2014 nyarán 395 mm csapadék hullott az aszályos időszakok ellenére) magyarázható.

A Pusztaszer 6 A akácos faállomány alatti talajvízszint a nyugalmi időben mintegy $20 \mathrm{~cm}$-rel maradt alatta a kontrollterületen mértnek. Májusban aztán ez az eltérés pár nap alatt közel fél méterrel növekedett, majd a későbbiekben jelentős talajvízszint-változást nem észleltünk, még a nagy csapadékok idején sem. A jelenség - a vegetációs időszak elmúltát követő kiegyenlitődési folyamatok hiányában - nem vezethető vissza egyértelmüen a növényi vízfogyasztásra, ugyanakkor az órás felbontású talajvízszint észlelésen alapuló Whitemódszerrel ki tudtuk mutatni a talajvízből történő közvetlen vízfelvételt. Ennek értékét a 2014-es vegetációs időszakban 0,9 mm/napra (136 mm/veg. idősz.) becsültük.

\section{Talajnedvesség, és az abból számolt evapotranszspiráció}

A talajban lévő nedvesség mennyiségére, ill. annak időbeli változására a talaj tulajdonságain és a felszínt borító növényi vegetáción túl a vizsgált talajszelvény aktuális vízháztartási viszonyai hatnak. Ennek megfelelően a talaj nedvességtartalmának ismerete legtöbbször nélkülözhetetlen a vízforgalmi számításoknál.

A bócsai mintaterületek felső $80 \mathrm{~cm}$-ének átlagos talajnedvesség-változását a 7. ábra mutatja be.

A görbék mindegyike vegetációs időszakbeli szárazodást, és nyugalmi időszaki nedvesedést mutat. A parlagterület nedvességtartalma mutatja a legnagyobb dinamikát, ez a terület reagált leginkább a csapadékra. 


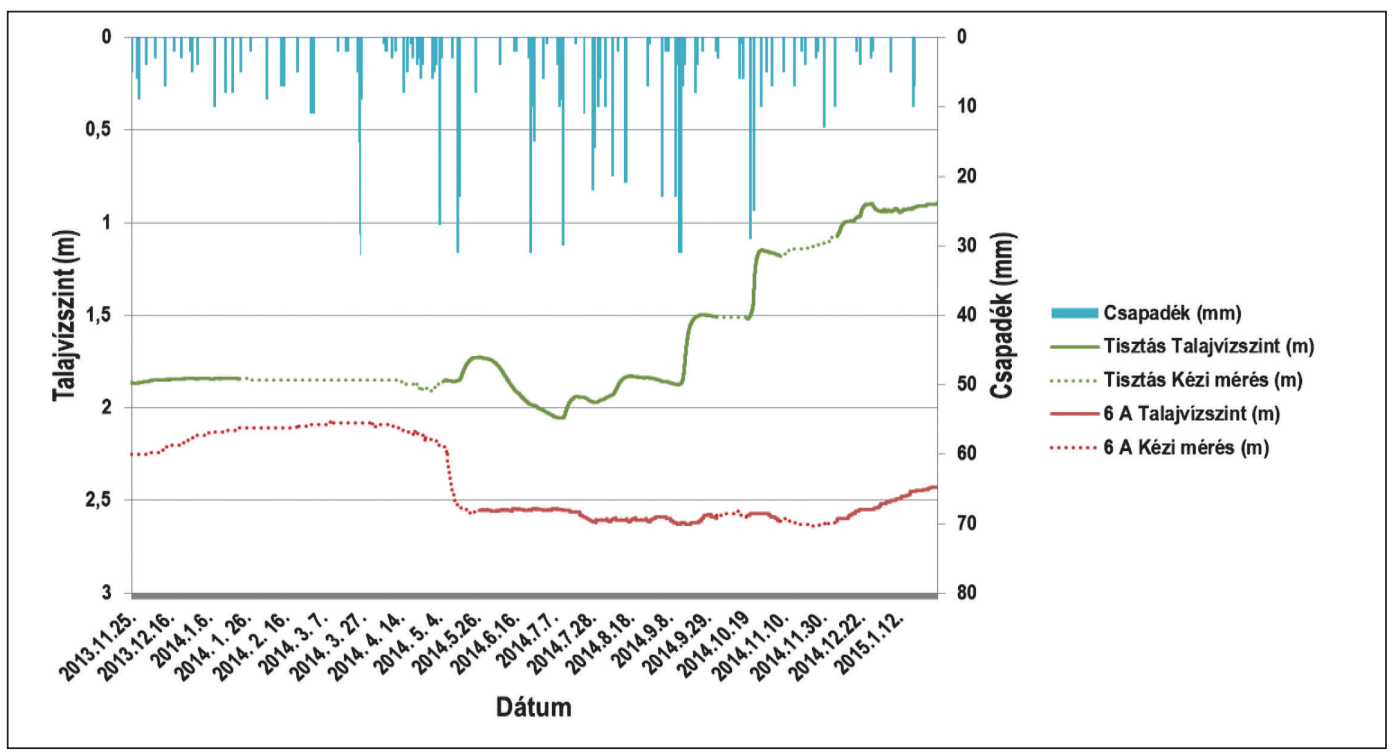

6. ábra: A talajvízszint változása a pusztaszeri mintaterületen a napi csapadék függvényében Figure 6: Changes in the watertable in Pusztaszer depending on the precipitation

Az erdei mintaterületek nedvességgörbéi kisebb amplitúdóval, de jól követik a kontrollterület görbéjét. A két erdőtalaj nedvességtartalma hasonló, s átlagban mintegy $2 \%$-kal alacsonyabb a parlagterületénél.

A talaj nedvességkészletének csökkenéséből számított evapotranszspiráció átlagos napi értéke a parlagterületen 0,5-0,8 mm, az erdeifenyvesben $0,3-0,5 \mathrm{~mm}$, a szürke nyárasban pedig 0,4-0,5 mm értéknek adódott attól függően, hogy az egyes csapadékmentes időszakokból nyert adatok mediánját, vagy napok számával súlyozott átlagát vettük.

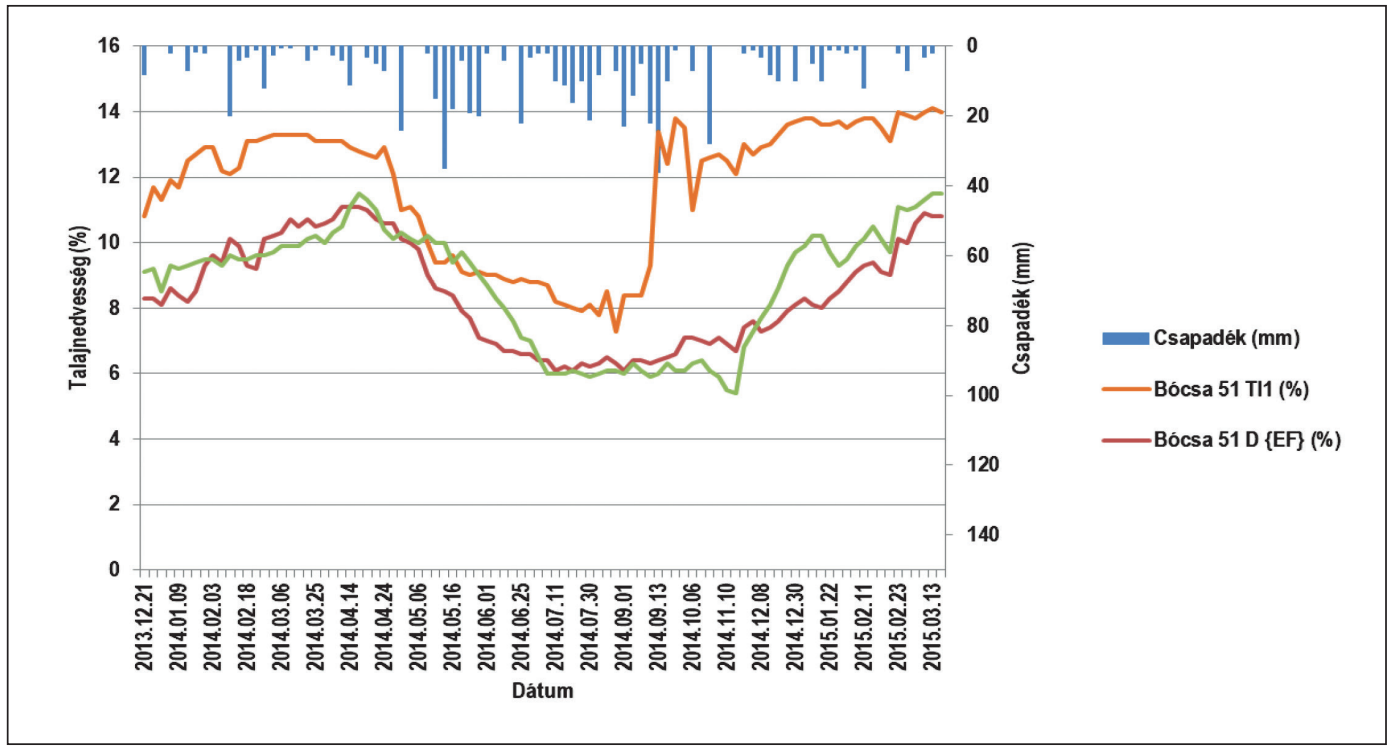

7. ábra: A talaj felső $80 \mathrm{~cm}$-es rétegének nedvességtartalom-változása a bócsai mintaterületen Figure 7: Fluctuation of the soil moisture in Bócsa PT-1 (upper $80 \mathrm{~cm}$ ) 
A fentiek igazak a pusztaszeri mérésekre is (8. ábra) azzal az eltéréssel, hogy az akácos alatt átlagosan nem 2\%-kal, hanem 4\%-kal alacsonyabb a talaj nedvességtartalma a kontrollterülethez képest.

Az evapotranszspirációt a parlagterületen 0,3-0,5 $\mathrm{mm} / \mathrm{nap}$, az akácosban 0,3 $\mathrm{mm} /$ nap nagyságúnak számítottuk. A módszertani részben leírtak szerint a fenti evapotranszspirációs értékek a felső $80 \mathrm{~cm}$-es talajrétegre vonatkoznak, és nem tartalmazzák a szürke nyáras $1,5 \mathrm{~mm} /$ napra és az akácos $0,9 \mathrm{~mm} /$ napra becsült közvetlen talajviz-fogyasztását.

Az automatizált talajnedvesség-mérések sajnos nem váltották be a hozzájuk füzött reményeket: a gyakori meghibásodások miatt csak a 2013/14-es nyugalmi időszakról vannak értékelhető adataink. Ezekből sajnos megfelelő következtetéseket nem lehet levonni, legalább egy teljes év adatára lenne szükség. Tovább kell dolgoznunk a szondák kalibrálásán is, mert a szárítószekrényes kontrollmérések nem támasztották kellöképpen alá az eredmények elfogadhatóságát.

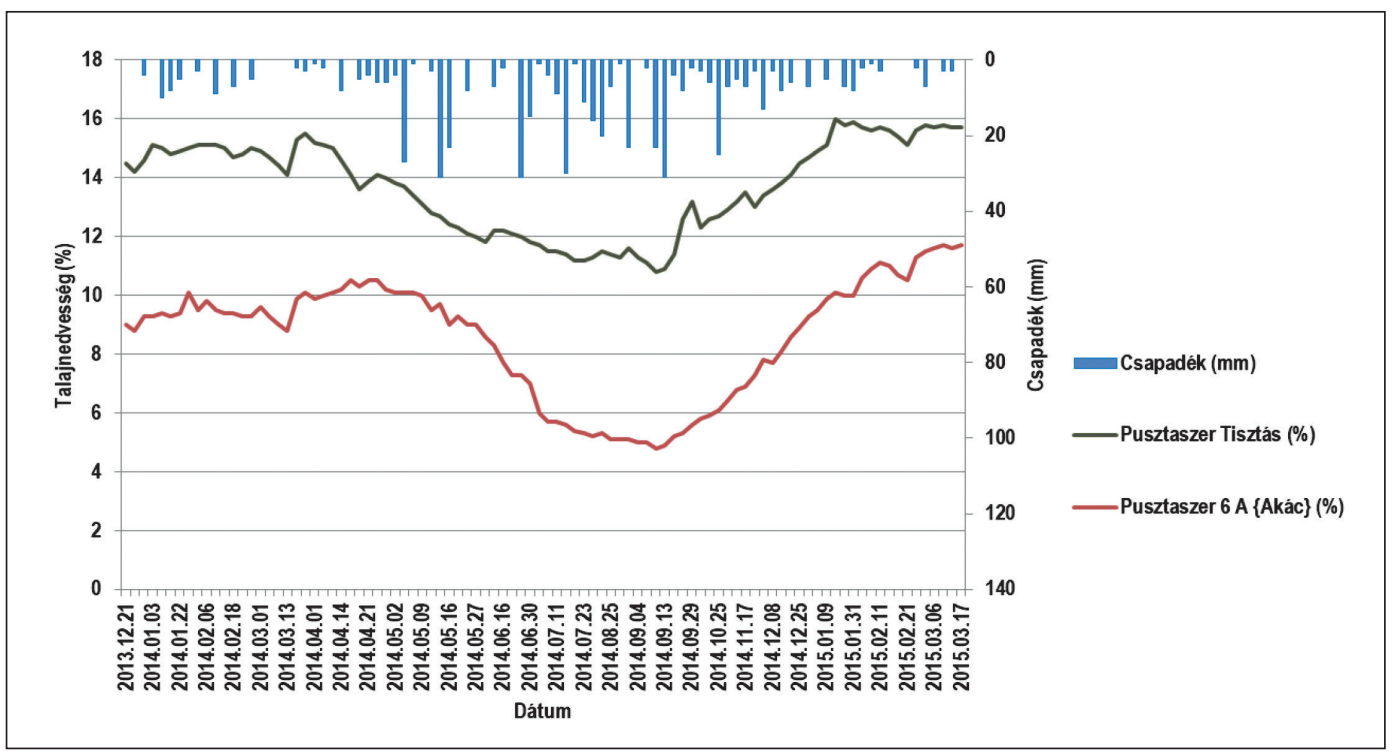

8. ábra: A talaj felső $80 \mathrm{~cm}$-es rétegének nedvességtartalom változása a puszatszeri mintaterületen

Figure 8: Fluctuation of the soil moisture in Pusztaszer PT-1 (upper $80 \mathrm{~cm}$ )

\section{A kísérleti területek vízforgalma}

A vízforgalom fentebb ismertetett elemeinek egyszerüsített vízháztartási egyenletbe rendezésével kapott vízforgalmat a 4. táblázat mutatja be. Tekintettel arra, hogy a mélybeszivárgás ( $80 \mathrm{~cm}$ alá) értéke maradéktagként adódott, magán viseli az összes többi vízforgalmi elem számítási hibáját. Mivel az adatok mindössze egyetlen, 400 mm feletti csapadékkal jellemezhető vegetációs időszak méréseit tükrözik, erősen tájékoztató jellegüek.

Az adatok tendenciájából kiolvasható, hogy a talaj felső $80 \mathrm{~cm}$-ére számított evapotranszspiráció értékei nem különböznek jelentősen egymástól. Ugyanez igaz a vízkészlet változásra is: a vegetációs időszak végére 29-38 mm-rel csökken a felső $80 \mathrm{~cm}$ nedvességkészlete valamennyi vizsgált területen.

A vízforgalombeli különbségeket elsősorban az intercepcióbeli eltérések és a két érintett állomány közvetlen talajvízfogyasztása okozza. Finomítani lehetne az eredményeken, ha az evapotranszspirációt a jövőben fel tudnánk bontani talajfelszíni párolgásra és növényi vízfogyasztásra. 
4. táblázat: A mintaterületek vízforgalmának föbb komponensei Table 4: Water balance elements

\begin{tabular}{|l|c|c|c|c|c|}
\hline \multicolumn{1}{|c|}{ Időszak } & \multicolumn{5}{c|}{ 2014. 03. 31. - 2014. 09. 01. } \\
\hline Faállomány & $\begin{array}{c}\text { Bócsa 51 D } \\
(\text { EF) }\end{array}$ & $\begin{array}{c}\text { Bócsa 51 E } \\
(\text { SZNY) }\end{array}$ & $\begin{array}{c}\text { Bócsa 51 TI1 } \\
\text { (Gyep) }\end{array}$ & $\begin{array}{c}\text { Pusztaszer } \\
\text { (Gyep) }\end{array}$ & Pusztaszer 6 A (A) \\
\hline Intercepció $(\mathrm{mm})$ & 98 & 81 & 30 & 28 & 102 \\
\hline Evapotranszspiráció $(\mathrm{mm})$ & $50-80$ & $60-70$ & $70-122$ & $46-70$ & $40-47$ \\
\hline Mélybeszivárgás $(0,8 \mathrm{~m} \rightarrow)(\mathrm{mm})$ & $286-316$ & $309-319$ & $314-366$ & $338-368$ & $298-303$ \\
\hline Talaj vízkészlet-változása $(\mathrm{mm})$ & -36 & -32 & -38 & -29 & -38 \\
\hline Csapadék összesen $(\mathrm{mm})$ & 428 & 428 & 428 & 407 & 407 \\
\hline $\begin{array}{l}\text { Vízfelvétel a kapilláris zónából } \\
(\mathrm{mm})\end{array}$ & - & 230 & - & - & 136 \\
\hline
\end{tabular}

\section{ÖSSZEFOGLALÁS}

A Duna-Tisza közi homokhátság vízháztartásával, az erdőállományok talajvízre gyakorolt hatásával több erdészeti és vízügyi szakember is foglalkozott. A szakemberek véleménye eltérő a témát illetően.

Munkánk során erdő- és gyepterületek vízforgalmát vizsgáltuk meteorológiai, talajvízszint, talajnedvesség tartalom és intercepciós mérések segítségével. Az evapotranszspiráció értékét az egyszerűsített vízháztartási egyenlet csapadékmentes időszakokra történő felírásával határoztuk meg. A kapilláris zónából történő vízfelvételt a White-módszer alapján becsültük.

A Bócsán mért meteorológiai adatok tekintetében elmondhatjuk, hogy rendkívül száraz (2012) és igen csapadékos (2014) év is volt a vizsgált időszakban. Az intercepciós vizsgálatokban ezt a sokszínűséget nagyon jól ki tudtuk használni. A vízmérleget a csapadékos 2014-es év vegetációs időszakára állítottuk fel.

Az egyes évek vegetációs időszakának intercepciójában jelentős eltéréseket találtunk, melyek jól magyarázhatóak a meteorológiai adatokkal. Az erdeifenyves intercepciója 23-28\% között változott, a szürke nyáras esetében 19-21\% volt. Különösen fontosnak találtuk a kis csapadékok számának jelentőségét. A szürke nyáras és az erdeifenyves koronáján áthulló csapadék mennyisége között nem volt jelentős eltérés, az intercepciós különbségeket a nyárasban mért nagyobb törzsi lefolyás adta.

A talajvízszint adatainak elemzése során kimutathatóak voltak a gyep és az erdő közötti különbségek. A parlagterületek alatt - ha csak 5-10 cm-rel is - de mindig magasabban állt a talajvíz szintje, mint az erdőállományok alatt.

Erdeifenyő esetében az erdőállomány alatti vegetációs időszaki talajvízteknő nem volt kimérhető. Ez alapján feltételezhető, hogy az állomány közvetlenül a talajvízből nem fogyaszt - talajvízszintre gyakorolt hatása inkább az intercepción keresztül érvényesül. Talajvízből való közvetlen vízfogyasztást a White-módszerrel sem tudtunk kimutatni.

A szürke nyáras alatt megfigyelt talajvízgörbe az állomány közvetlen talajvízfogyasztására utal; ennek értékét a 2014-es vegetációs időszakban a White-módszerrel $1,5 \mathrm{~mm} /$ napra $(230 \mathrm{~mm} / \mathrm{veg}$. idősz.) becsültük. Ugyan ezen érték az akácos alatt 0,9 mm/napnak (136 mm/veg. idősz.) adódott.

A talaj nedvességtartalma és annak dinamikája valamennyi vizsgált területen vegetációs időszakbeli szárazodást, és nyugalmi időszaki nedvesedést mutatott. A parlagterületek nedvességtartalma mutatta a legnagyobb dinamikát, e területek reagáltak leginkább a csapadékra. Az erdei mintaterületek nedvességgörbéi kisebb amplitúdóval, de jól követték a kontrollterületek görbéit. A fenyves és nyáras alatt átlagosan 2\%-kal, az akácos alatt 4\%-kal alacsonyabb nedvességtartalmakat mértünk. 
A talaj nedvességkészletének csökkenéséböl számított evapotranszspiráció átlagos napi értéke a parlagterületeken $0,3-0,8 \mathrm{~mm}$, az erdeifenyvesben $0,3-0,5 \mathrm{~mm}$, a szürke nyárasban $0,4-0,5 \mathrm{~mm}$, az akácosban pedig 0,3 mm értékek adódtak attól függően, hogy az egyes csapadékmentes időszakokból nyert adatok mediánját, vagy a napok számával súlyozott átlagát vettük. A vizforgalombeli különbségeket elsősorban nem ez, hanem az intercepcióbeli eltérések és a nyáras, ill. az akácos állomány közvetlen talajvizfogyasztása okozta.

\section{FELHASZNÁLT IRODALOM}

Führer E. 2010: A fák növekedése és a klíma. „KLÍMA-21” Füzetek 61: 98-107.

Gácsi Zs. 2000: A talajvizszint észlelés, mint hagyományos, s a vizforgalmi modellezés, mint új módszer Alföldi erdeink vízháztartásának vizsgálatában. Doktori (Ph.D) értekezés, NyME Sopron, 69-93.

Gribovszki Z., Kalicz P. \& Szilágyi J. 2009: Napi periódusú ingadozás a hidrológiai jellemzőkben. Hidrológiai közlöny 89(2): 23-37.

Hagyó A., Rajkai K. \& Nagy Z. 2006: Effect of forest and grassland vegetation on soil hydrology in Mátra Mountains (Hungary). Biologia 61(Suppl. 19): S261-S265. DOl: 10.2478/s11756-006-0169-7

Járó Z. 1980: Intercepció a gödöllöi kultúr erdei ökoszisztémában. Erdészeti kutatások 73(1): 7-17.

Loheide S. P., Butler J. J. \& Gorelick S. M. 2005: Estimation of groundwater consumption by phreatophytes using diurnal water table fluctuations: A saturated-unsaturated flow assessment. Water Resources Research 41(7) W07030. DOI:10.1029/2005WR003942

Major P. 1974: Síkvidéki erdők hatásának vizsgálata a talajvizpárolgás és tényleges beszivárgás folyamataira. Hidrológia Közlöny 54(6): 281-288.

Major P. \& Neppel F. 1988: A Duna-Tisza közi talajízszint-süllyedések. Vizügyi Közlemények 70(4): 605-626.

Major P. 1994: Talajvízszint-süllyedések a Duna-Tisza közén. In: Pálfai Imre (ed): A Duna-Tisza közi hátság vízgazdálkodási problémái, A Nagyalföld alapitvány kötetei 3, Nagy-alföld Alapitvány, Békéscsaba, 17-24.

Major P. 2002: Síkvidéki erdők hatása a vizháztartásra, Hidrológiai Közlöny 82(6):319-323.

Moltschanow A. A. 1957: Die hydrologsche Rolle des Kiefernwaldes auf Sandboden. Deutscher Bauernverlag Berlin, $157-158$.

Móricz N. 2011: Egy erdő és parlagterület vizforgalmának összehasonlitó vizsgálata. Doktori (Ph.D) értekezés, NyME Sopron, 35-79.

Pálfai I. 1995: A Duna-Tisza közi hátság vízgazdálkodási problémái és megoldásuk lehetséges útjai. Vizügyi Közlemények 77(2): 144-161.

Pálfai I. 2010: A Duna-Tisza közi hátság vízgazdálkodási sajátosságai. Hidrológia Közlöny 90(1): 40-44.

Sitkey J. 1999: Erdő és talajviz kapcsolatára, valamint az erdőnek a kis vízgyüjtők hozamára vonatkozó kutatások ismertetése. In: Gácsi Zs. (ed): Erdö-Vizz, szemelvények erdészeti kutatási és gyakorlati munkákból. Kecskemét, 22-34. Szász G. \& Tőkei L. 1997: Meteorológia mezőgazdáknak, kertészeknek, erdészeknek. Mezőgazda Kiadó, Budapest. Szodfridt I. 1974: A talajvíz és a vegetáció kapcsolata Duna-Tisza-köze homokterületén. Abstracta Botanica (2): 39-42.

Szodfridt I. 1990: Hozzászólás: Major Pál és Neppel Ferenc: A Duna-Tisza közi talajvizszint-süllyedése címü cikkéhez. Vizügyi Közlemények 72(3): 287-291.

Szodfridt I. 1993: Az erdő és a talajizek kapcsolata Duna-Tisza közi hátságon. Hidrológia Közlöny 73(1): 44-45.

White W. N. 1932: A method of estimating ground-water suppliesbased on discharge by plants and evaporation from soil:

Results of investigations in Escalante Valley, Utah. U.S.Geological Survey Water-Supply Paper 659-A: 1-106. 